\title{
Acute effects of dexamethasone on cation transport in colonic epithelium
}

\author{
G I SANDLE AND F McGLONE
}

From the Department of Medicine, (University of Manchester School of Medicine), Hope Hospital, Salford.

SUMMARY Single pharmacological doses of glucocorticoid hormones stimulate net $\mathrm{Na}^{+}$and water absorption, $\mathrm{K}^{+}$secretion and electrical potential difference in rat distal colon and human rectum after five hours. To determine the cellular basis of these effects, the $\mathrm{Na}^{+}$and $\mathrm{K}^{+}$transport properties of epithelial cell membranes in rat distal colon were studied in vitro five hours after in vivo treatment with dexamethasone $600 \mu \mathrm{g} / 100 \mathrm{~g}$ body weight. Compared with control tissues, dexamethasone increased transepithelial voltage 3.5 -fold $(\mathrm{p}<0.001)$ and short circuit current 4.5 -fold $(p<0.001)$, and decreased total resistance by $20 \%(p<0.005)$. Measurements of cell membrane voltages obtained with intracellular microelectrodes indicated that the dexamethasoneinduced rise in transepithelial voltage reflected a significant decrease $(p<0.05)$ in apical membrane voltage, consistent with the induction of apical $\mathrm{Na}^{+}$channels and the stimulation of electrogenic $\mathrm{Na}^{+}$absorption. Apical addition of $10^{-4} \mathrm{~mol} / \mathrm{l}$ amiloride $\left(\mathrm{a} \mathrm{Na} \mathrm{Na}^{+}\right.$channel blocker) and then 30 $\mathrm{mmol} / \mathrm{l}$ tetraethylammonium chloride (TEA; a $\mathrm{K}^{+}$channel blocker) to control tissues had little or no effect on transepithelial electrical parameters, indicating the absence of significant apical $\mathrm{Na}^{+}$ and $\mathrm{K}^{+}$conductances. In contrast, in dexamethasone treated tissues, amiloride and TEA produced electrical changes that were consistent with the inhibition of glucocorticoid-induced apical $\mathrm{Na}^{+}$and $\mathrm{K}^{+}$conductances. Kinetic studies of the basolateral membrane $\mathrm{Na}^{+}-\mathrm{K}^{+}$pump revealed that five hours after administration, dexamethasone had no effect on the maximum capacity of the pump for $\mathrm{Na}^{+}$transport, but significantly increased the affinity of the pump for $\mathrm{Na}^{+}$, and the number of $\mathrm{Na}^{+}$ ions binding to each pump site. Thus, the acute stimulatory effects of dexamethasone on distal colonic $\mathrm{Na}^{+}$absorption and $\mathrm{K}^{+}$secretion reflect increased apical membrane conductance to $\mathrm{Na}^{+}$ and $\mathrm{K}^{+}$, and an increase in the 'efficiency' of the basolateral membrane $\mathrm{Na}^{+}-\mathrm{K}^{+}$pump.

Previous studies have shown that ion transport processes in mammalian colon are readily influenced by changes in circulating levels of corticosteroid hormones. ${ }^{1-\infty}$ Chronic administration of mineralocorticoid or glucocorticoid hormones generally produces similar effects in vivo, which include stimulation of $\mathrm{Na}^{+}$absorption, $\mathrm{K}^{+}$secretion, and mucosal $\mathrm{Na}^{+}-\mathrm{K}^{+}-$ATPase activity. ${ }^{-\infty}$ The initial effects are rapid, and perfusion studies in rat colon have shown that a single pharmacological dose of the glucocorticoid dexamethasone $(600 \mu \mathrm{g} / 100 \mathrm{~g}$ body weight $)$ increases $\mathrm{Na}^{+}$and water absorption, $\mathrm{K}^{+}$secretion,

Address for correspondence: Dr G I Sandle, Department of Medicine, Clinical Sciences Building. Hope Hospital. Eccles Old Road. Salford M6 8HD.

Received for publication 6 October. 1986. and transmural electrical potential difference (pd) after only five hours, while mucosal $\mathrm{Na}^{+}-\mathrm{K}^{+}$ATPase activity (which constitutes the basolateral membrane $\mathrm{Na}^{+}-\mathrm{K}^{+}$pump) is unchanged.' Rectal dialysis studies indicate that single pharmacological doses of the glucocorticoids hydrocortisone $(100 \mathrm{mg}$ ) and methylprednisolone $(40 \mathrm{mg})$ also enhance $\mathrm{Na}^{+}$and water absorption, $\mathrm{K}^{+}$secretion, and pd after five hours in both normal subjects and patients with active ulcerative colitis. ${ }^{x}$ These findings are of particular interest as they suggest that systemically administered glucocorticoids decrease diarrhoea in ulcerative colitis by stimulating colonic $\mathrm{Na}^{+}$and water absorption, as well as by their better known antiinflammatory action.

The present study was done in rat distal colon to 
determine the cellular basis for the acute effects of glucocorticoid hormones on colonic cation transport. Although in vivo studies indicate that glucocorticoids induce an early increase in electrogenic $\mathrm{Na}^{+}$absorpion, ${ }^{7}$ it is unclear whether this reflects enhanced $\mathrm{Na}$. entry at the apical membrane, increased activity of the basolateral membrane $\mathrm{Na}^{+}-\mathrm{K}$ pump, or a combination of these possibilities. It is also unclear whether the accompanying increase in $\mathrm{K}^{\prime}$ secretion is passive - that is, paracellular and pd-dependent, or active - that is, transcellular and pd-independent, or a combination of active and passive transport. In order to determine the acute effects of glucocorticoid hormones on colonic epithelial cell membranes, the conductive properties of the apical membrane to $\mathrm{Na}$ ' and $\mathrm{K}^{\prime}$, and the kinetics of the basolateral membrane $\mathrm{Na}^{+}-\mathrm{K}^{+}$pump, have been compared in normal rat distal colon and distal colon from animals treated with a single dose of dexamethasone.

\section{Methods}

ANIMALS

Non-fasting male Sprague-Dawley rats weighing 250-300 $\mathrm{g}$ were used in all experiments. The glucocorticoid treated animals were injected intraperitoneally with a single $600 \mu \mathrm{g} / 100 \mathrm{~g}$ body weight dose of dexamethasone phosphate five hours before removing the colon. Control and dexamethasone treated animals had received $20 \mathrm{~g} /$ day of regular Purina chow and tap water ad libitum. After removal, the colon was rinsed with $\mathrm{NaCl}$-Ringer solution at $37^{\circ} \mathrm{C}$ containing (in $\mathrm{mmol} / \mathrm{l}$ ): $\mathrm{Na}^{+} 136 \cdot 2 ; \mathrm{K}^{+} 7 \cdot 0$; $\mathrm{Cl} 121 ; \mathrm{Ca}^{++} 2 \cdot 0 ; \mathrm{Mg}^{++} 1 \cdot 2 ; \mathrm{HCO}_{3} 25 ; \mathrm{H}_{2} \mathrm{PO}_{4} 1 \cdot 2 ;$ $\mathrm{SO}_{4} \quad 1 \cdot 2$; glucose $11 \cdot 1$ and gassed with $95 \% \mathrm{O}_{2} / 5 \%$ $\mathrm{CO}_{2}(\mathrm{pH} 7 \cdot 4)$. A $2-3 \mathrm{~cm}$ segment of distal colon was obtained $3 \mathrm{~cm}$ proximal to the anus, stripped of serosa and muscle layers, and mounted vertically between modified open topped Ussing chambers as previously described." Both sides of the tissue were bathed with $12 \mathrm{ml}$ of stirred, gassed $\mathrm{NaCl}$-Ringer solution at $37^{\circ} \mathrm{C}$ and $\mathrm{pH} 7 \cdot 4$. Tissue area was $1 \mathrm{~cm}$.

Transepithelial voltage $\left(\mathrm{V}_{1}\right)$ was measured with 1 $\mathrm{mol} / \mathrm{l} \mathrm{KC1}-4 \%$ agar bridges placed on either side of the tissue and attached to calomel half-cells. Two second transepithelial current pulses $\left(120 \mu \mathrm{A} / \mathrm{cm}^{2}\right.$; Anapulse stimulator Model 302-T, and stimulus isolation unit Model 305, WP Instruments, New Haven, CT, USA) were passed via $\mathrm{Ag} / \mathrm{AgCl}$ electrodes placed at the back of each chamber. Glass fibre-filled microelectrodes (tip diameter $<0.5 \mu \mathrm{m}$ ) were prepared with a horizontal pipette puller (Campden Instruments, London, Model 753), filled with $0.5 \mathrm{~mol} / \mathrm{l} \mathrm{KC1}$, and had tip resistances of $40-100$ $\mathrm{M} \Omega$ in $\mathrm{NaCl}$-Ringer solution. Cells were impaled from the apical (mucosal) side of the tissue, and microelectrodes were positioned with an accuracy of $1 \mu \mathrm{m}$ using a remotely controlled three dimensional hydraulic micromanipulator (Narishige Scientific Instruments, Tokyo, Japan, Model MO-103). Membrane voltages were measured within $\pm 0 \cdot 1 \mathrm{mV}$ with a high impedance electrometer (WP Instruments, Model 750), and microelectrodes were referenced to the serosal solution such that basolateral membrane voltage $\left(V_{h}\right)$ was monitored directly. The entire apparatus was mounted on an anti-vibration table. $V_{t}$ and $V_{h}$ were monitored on digital voltmeters interfaced with a microcomputer (BBC Model B) and a dual beam oscilloscope, and recorded on a chart recorder and microcomputer driven printer.

Apical membrane voltage $\left(V_{a}\right)$ was calculated as $V_{a}=V_{t}-V_{h}$, and the ratio of the changes in apical and basolateral membrane voltages in response to the transepithelial current pulse was assumed to equal the membrane resistance ratio, $\alpha$ ( $\alpha=$ ratio of the apical to basolateral membrane resistance). Total tissue resistance, $R_{t}$ (calculated as $R_{t}=\triangle V_{t} / I$, where $\triangle V_{1}$ is the change in transepithelial voltage in response to the transepithelial current pulse, I), and $\alpha$, were corrected for series resistance of the bathing solution as previously described."'

Initial studies were done with microelectrodes to determine the effects of dexamethasone on the basal electrical properties of the epithelium when bathed in $\mathrm{NaCl}$-Ringer solution. After 25-35 minutes, when transepithelial electrical parameters were constant, three to five cell impalements lasting 45-90 seconds were performed applying the transepithelial current pulse at five second intervals. The $\mathrm{Na}^{+}$channel blocker amiloride (a gift of Merck, Sharp and Dohme) was then added to the mucosal solution to a final concentration of $10^{-4} \mathrm{~mol} / \mathrm{l}$ and three to five impalements obtained five minutes later. Impalements were judged to be successful if (i) $V_{b}$ reached a steady value after 10 seconds, (ii) $V_{b}$ and $\alpha$ remained stable during the impalement, (iii) the microelectrode tip resistance was unchanged by the impalement, and (iv) the microelectrode recorded the baseline voltage $\left(\mathrm{V}_{t}\right)$ upon withdrawal. Average values of microelectrode measurements were calculated for each tissue under pre- and postamiloride conditions before obtaining a mean value for the group.

In further studies in which only transepithelial measurements were obtained, the effects of the mucosal addition of the $\mathrm{K}$ channel blocker tetraethylammonium chloride (TEA: final concentration $30 \mathrm{mmol} / \mathrm{l})$ were determined in distal colon from control and dexamethasone treated animals, having first added 10 mol/l amiloride to block apical membrane $\mathrm{Na}^{+}$channels.

Finally, the activity of the basolateral membrane $\mathrm{Na}^{+}-\mathrm{K}^{+}$pump in the two experimental groups 
was determined using a technique similar to that previously reported."' Tissues were bathed on the mucosal side with $\mathrm{K}^{*}$ gluconate Ringer solution containing (in mmol/l): $\mathrm{K}^{\prime} 140 ; \mathrm{HCO}_{3} 25 ; \mathrm{Ca}^{++} 10$ (methane sulphonate); $\mathrm{Mg}^{++} 1 \cdot 2 ; \mathrm{SO}_{4} \quad 1 \cdot 2 ; \mathrm{H}_{2} \mathrm{PO}_{4}$ $2 \cdot 3 \mathrm{MeSO}_{3}$ 20; gluconate $113 \cdot 8$, and glucose 11.1; and on the serosal side with $\mathrm{Na}^{\prime}$ gluconate Ringer solution (similar to $\mathrm{NaCl}$ Ringer solution, but $\mathrm{Cl}^{-}$ replaced with equimolar gluconate). The polyene antibiotic nystatin (Sigma Chemical Co., St. Louis, MO, USA) was then added to the mucosal solution to a final concentration of $480 \mathrm{U} / \mathrm{ml}$. This drug combined rapidly with lipid in the apical membrane, forming water filled pores which rendered the membrane freely permeable to monovalent ions, "resulting in a decrease in $R_{t}$ while $V_{t}$ increased to about $40 \mathrm{mV}$ (mucosal side negative). When the effects of nystatin were complete (generally within 5 minutes), the serosal solution was replaced with $\mathbf{K}^{+}$gluconate Ringer solution, leading to a rapid fall in $V_{h}$ and thus $V_{t}$ and the equivalent short circuit current, Isc (Isc $\left.=V_{t} / R_{t}\right)$ to zero. Equal aliquots of $\mathrm{Na}^{+}$gluconate were then added first to the serosal solution (where they had no effect) and then to the mucosal solution to final concentrations of $10,20,30,40$, and $50 \mathrm{mmol} / \mathrm{l}$. Increases in mucosal (and thus intracellular) $\mathrm{Na}^{+}$ rapidly hyperpolarised the basolateral membrane, as reflected by the increases in $V_{1}$ and Isc, with steady values occurring after 2-3 minutes. The kinetics of the basolateral $\mathrm{Na}^{+}-\mathrm{K}^{+}$pump were assessed by plotting $\triangle$ Isc against the mucosal $\mathrm{Na}^{+}$concentration ([Na $\left.\left.{ }^{+}\right]\right)$using an iterative least-squares curve-fitting routine to fit the data to a model of highly cooperative binding":

$$
\Delta I s c=\frac{I_{\max }}{1+\left(\frac{K_{m}}{\left[\mathrm{Na}^{+}\right]}\right)^{n}}
$$

where $\mathrm{Isc}_{\text {max }}=$ the apparent maximum short-circuit current, $\mathrm{K}_{\mathrm{m}}=$ the mucosal $\mathrm{Na}^{\prime}$ concentration required to achieve $50 \% \mathrm{Isc}_{\max }$, and $\mathrm{n}=$ the number of $\mathrm{Na}^{+}$ions binding to each $\mathrm{Na}^{+}-\mathrm{K}^{+}$pump site.

Results are expressed as mean \pm SEM for each group of tissues. Statistical comparisons were made using the two tailed Student's $t$ test for paired or unpaired data as appropriate. ${ }^{13}$

\section{Results}

The effects of dexamethasone on the basal transepithelial electrical properties of rat distal colon, and their sensitivity to amiloride, are shown in Table 1. Compared with control tissues, dexamethasone increased basal transepithelial voltage
Table 1 Effect of dexamethasone on basal electrical properties of rat distal colon

\begin{tabular}{|c|c|c|c|}
\hline & $\begin{array}{l}V_{1} \\
(m V)\end{array}$ & $\begin{array}{l}R_{t} \\
\left(\Omega\left(\mathrm{cm}^{2}\right)\right.\end{array}$ & $\begin{array}{l}\text { Isc } \\
\left(\mu A / \mathrm{cm}^{2}\right)\end{array}$ \\
\hline \multicolumn{4}{|l|}{ Control $(n=23)$} \\
\hline Basal & $-5 \pm 1$ & $185 \pm 6$ & $26 \pm 4$ \\
\hline +amiloride & $-5 \pm 1$ & $182 \pm 6$ & $25 \pm 4$ \\
\hline $\mathrm{p}^{*}$ & NS & NS & NS \\
\hline \multicolumn{4}{|c|}{$\begin{array}{l}\text { Dexamethasone } \\
\text { treated }(n=20)\end{array}$} \\
\hline Basal & $-17 \pm 2 \dagger$ & $148 \pm 9+$ & $115 \pm 26 \dagger$ \\
\hline +amiloride & $-5 \pm 1$ & $165 \pm 11$ & $33 \pm 7$ \\
\hline $\mathrm{p}^{*}$ & $<() \cdot()() 1$ & $<0 \cdot()() 1$ & $<() \cdot()() 1$ \\
\hline
\end{tabular}

Results are expressed as mean \pm SEM. $V_{t}=$ transepithelial voltage (mucosal surface negative); $R_{t}=$ total resistance; Isc =short-circuit current; $\mathbf{n}$ is the number of tissues studied.

*difference between basal and postamiloride value; $t=p<0 \cdot(0) 1$;

$\ddagger=\mathrm{p}<0.005$ compared with basal value in control tissues.

3.5-fold $(p<0 \cdot 001)$ and basal short circuit current $4 \cdot 5$ fold $(p<0 \cdot 001)$, and decreased total resistance by $20 \%(p<0 \cdot 005)$. Table 2 shows that the dexamethasone induced rise in transepithelial voltage reflected significant depolarisation of the apical membrane $(p<0 \cdot 05)$, a change which is consistent with the induction of $\mathrm{Na}^{+}$channels in the apical membrane.

Tables 1 and 2 also show that the apical (mucosal) addition of amiloride had no effect on transepithelial or microelectrode measurements in distal colon from control animals, indicating that amiloride sensitive apical $\mathrm{Na}^{+}$channels are normally absent from this epithelium under in vitro conditions. In contrast, in dexamethasone treated tissues, amiloride significantly decreased the transepithelial voltage

Table 2 Effect of dexamethasone on transepithelial and cell membrane voltages in rat distal colon

\begin{tabular}{|c|c|c|c|c|}
\hline & $\begin{array}{l}V_{1} \\
(m V)\end{array}$ & $\begin{array}{l}V_{a \prime} \\
(m V)\end{array}$ & $\begin{array}{l}V_{h} \\
(m V)\end{array}$ & $\begin{array}{l}\alpha(\% \text { of } \\
\text { basal value) }\end{array}$ \\
\hline \multicolumn{5}{|l|}{ Control $(n=9)$} \\
\hline Basal & $-4 \pm 1$ & $+48 \pm 3$ & $-52 \pm 3$ & 100 \\
\hline +amiloride & $-3 \pm 1$ & $+47 \pm 2$ & $-50 \pm 2$ & $96 \pm 17$ \\
\hline $\mathrm{p}^{*}$ & NS & NS & NS & NS \\
\hline \multicolumn{5}{|c|}{$\begin{array}{c}\text { Dexamethasone } \\
\text { treated }(n=5)\end{array}$} \\
\hline Basal & $-12 \pm 3+$ & $+37 \pm 3 \ddagger$ & $-49 \pm 2 \S$ & 10() \\
\hline +amiloride & $-3 \pm 1$ & $+49 \pm 3$ & $-52 \pm 4$ & $147 \pm 16$ \\
\hline $\mathrm{p}^{*}$ & $<0 \cdot(05$ & $<() \cdot 0) 5$ & NS & $<0 \cdot(05$ \\
\hline
\end{tabular}

Results expressed as mean \pm SEM. $V_{1}=$ transepithelial voltage (mucosal surface negative); $\mathrm{V}_{\mathrm{i}}=$ apical membrane voltage (positive with respect to cell interior); $\mathrm{V}_{\mathrm{h}}=$ basolateral membrane voltage (negative with respect to serosal solution); $\alpha=$ membrane resistance ratio (ratio of apical membrane and basolateral membrane resistance); $n$ is the number of tissues studied.

*difference between basal and postamiloride values; $\dagger=p<0 .(005$; $\ddagger \mathrm{p}<0.05 ; \S=\mathrm{NS}$ compared with basal value in control tissues. 
Table 3 Effect of dexamethasone on the sensitivity of rat distal colon to amiloride and tetraethylammonium chloride (TEA)

\begin{tabular}{|c|c|c|c|}
\hline & $\begin{array}{l}V_{t} \\
(m V)\end{array}$ & $\begin{array}{l}R_{t} \\
\left(\Omega \mathrm{cm}^{2}\right)\end{array}$ & $\begin{array}{l}I s c \\
\left(\mu \mathrm{A} / \mathrm{cm}^{2}\right)\end{array}$ \\
\hline \multicolumn{4}{|l|}{ Control $(n=14)$} \\
\hline Basal & $-6 \pm 1$ & $188 \pm 7$ & $31 \pm 6$ \\
\hline tamiloride & $-6 \pm 1$ & $186 \pm 7$ & $29 \pm 6$ \\
\hline $\mathrm{p}^{*}$ & NS & NS & NS \\
\hline $\begin{array}{l}+ \text { amiloride } \\
+ \text { TEA }\end{array}$ & $-9 \pm 1$ & $186 \pm 8$ & $50 \pm 5$ \\
\hline $\mathrm{p} \dagger$ & $<0 \cdot(0) 1$ & NS & $<0.001$ \\
\hline \multicolumn{4}{|c|}{$\begin{array}{l}\text { Dexamethasone } \\
\text { treated }(n=10)\end{array}$} \\
\hline Basal & $-18 \pm 4 \ddagger$ & $128 \pm 9 \ddagger$ & $137 \pm 25 \ddagger$ \\
\hline tamiloride & $-5 \pm 1$ & $143 \pm 12$ & $35 \pm 8$ \\
\hline $\mathrm{p}^{*}$ & $<0 \cdot(01$ & $<0 \cdot(02$ & $<0 \cdot 005$ \\
\hline $\begin{array}{l}+ \text { amiloride } \\
+ \text { TEA }\end{array}$ & $-7 \pm 1$ & $150 \pm 14$ & $47 \pm 8$ \\
\hline $\mathrm{p}^{\dagger}$ & $<0.005$ & $<0 \cdot 01$ & $<0 \cdot 001$ \\
\hline
\end{tabular}

Results are expressed as mean \pm SEM. $V_{1}=$ transepithelial voltage (mucosal surface negative); $\mathrm{R}_{\mathbf{t}}=$ total resistance; Isc $=$ short-circuit current; $\mathbf{n}=$ number of tissues studied.

*difference between basal and postamiloride value;

tdifference between postamiloride and postamiloride+TEA value;

$\ddagger=\mathrm{p}<0.001$ compared with basal valuc in control tissues.

$(\mathrm{p}<0 \cdot 001)$ and short circuit current $(\mathrm{p}<0 \cdot 001)$, and significantly increased total resistance $(p<0.001)$ (Table 1). As shown in Table 2, these changes reflected hyperpolarisation of the apical membrane $(\mathrm{p}<0.05)$ and a rise in apical membrane resistance, as judged by the $47 \%$ increase $(p<0.05)$ in the membrane resistances ratio, $\alpha$, and are consistent with amiloride inhibition of apical membrane $\mathrm{Na}^{+}$ channels. Thus, dexamethasone stimulates the early appearance of amiloride sensitive $\mathrm{Na}^{+}$conductive channels in the apical membrane which enhance apical $\mathrm{Na}^{+}$entry, resulting in a rise in electrogenic $\mathrm{Na}^{+}$absorption.

The effects of the sequential addition of amiloride and the $\mathrm{K}^{+}$channel blocker TEA to the mucosal solution bathing control and dexamethasone treated distal colon are shown in Table 3. Dexamethasone produced changes in the basal electrical properties and the amiloride sensitivity of the distal colon which were similar to those presented in Table 1. Amiloride again had no effect in control tissues, but produced changes in the dexamethasone treated tissues consistent with inhibition of electrogenic $\mathrm{Na}^{+}$absorption. The subsequent addition of TEA to control tissues significantly increased transepithelial voltage $(\mathrm{p}<0.001)$ and short circuit current $(\mathrm{p}<0.001)$ without changing total resistance. These changes are consistent with the inhibition of serosal to mucosal $\mathrm{K}^{+}$movement, although the lack of effect on total resistance suggests that there are normally relatively few TEA sensitive $\mathrm{K}^{+}$conductive channels in the

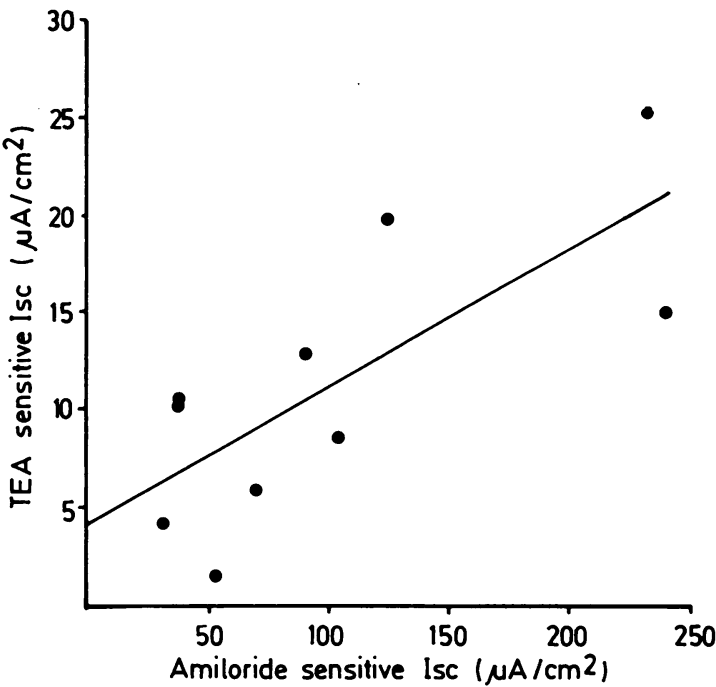

Fig. 1 Relationship between tetraethylammonium chloride (TEA)-sensitive and amiloride sensitive short circuit current (Isc) in rat distal colon $(n=10)$ five hours after treatment with dexamethasone $(600 \mu \mathrm{g} / 100 \mathrm{~g}$ body weight $)$. Line $(y=0.071 x+4 \cdot 219 ; r=0 \cdot 758 ; p<0 \cdot 02)$ is the least squares fit to the data, where the standard error for regression of y on $x=4 \cdot 7 \mu \mathrm{A} / \mathrm{cm}^{2}$.

apical membrane of rat distal colon. In contrast, addition of TEA to dexamethasone treated tissues produced a significant increase in total resistance $(p<0.01)$, as well as increases in transepithelial voltage and short circuit current, consistent with TEA inhibition of a relatively large, dexamethasoneinduced $\mathrm{K}^{+}$conductance in the apical membrane.

Figure 1 illustrates the relationship between the TEA sensitive and amiloride sensitive currents in the dexamethasone treated tissues. Individual tissues showed a wide variability in their response to dexamethasone, but overall, there was a significant positive correlation $(r=0 \cdot 758, p<0 \cdot 02)$ between the dexamethasone induced TEA sensitive $\mathrm{K}^{+}$current and the dexamethasone induced amiloride sensitive $\mathrm{Na}^{+}$current.

The ability of the basolateral membrane $\mathrm{Na}^{+}-\mathrm{K}^{+}$ pump to extrude $\mathrm{Na}^{+}$across the membrane in control and dexamethasone treated tissues is shown in Figure 2. The calculated maximum short circuit current - that is, the apparent $\mathrm{Isc}_{\max }$, in the control and dexamethasone treated tissues was similar $\left(73 \pm 1.0 \mu \mathrm{A} / \mathrm{cm}^{2}\right.$ and $74 \pm 1.0 \mu \mathrm{A} / \mathrm{cm}^{2}$, respectively). In the dexamethasone treated tissues, however, the apparent $\mathrm{K}_{\mathrm{m}}$ was lower $(11.5 \pm 0.2 \mathrm{mmol} / \mathrm{l})$ and the Hill coefficient was higher $(2 \cdot 2 \pm 0 \cdot 1)$ than the corresponding values in the control tissues $(14 \cdot 0 \pm 0 \cdot 4$ $\mathrm{mmol} / \mathrm{l}, \mathrm{p}<0 \cdot 01$ and $1 \cdot 4 \pm 0 \cdot 1, \mathrm{p}<0 \cdot 001$, respectively). 


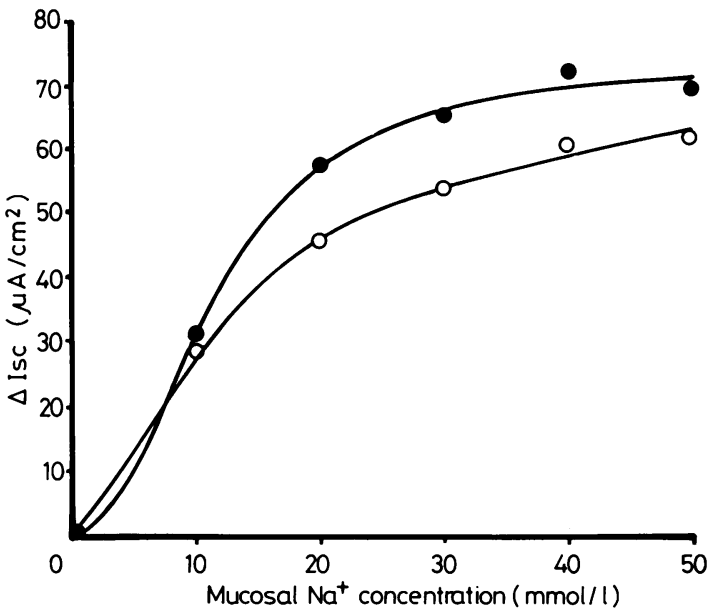

Fig. 2 Change in short circuit current from zero $(\triangle I s c)$ at increasing mucosal concentrations of $\mathrm{Na}^{+}$in tissues from 13 control $(\mathrm{O})$ and 14 dexamethasone treated $(\mathrm{O})$ animals. Each point represents that mean of the data at each concentration of $\mathrm{Na}^{+}$, and the curves through the points are the best fits to the equation describing the model of highly cooperative binding (see Methods). The best fit values for the lines are $I s c_{\text {max }}=73 \pm 1 \mu \mathrm{A} / \mathrm{cm}^{2}, K_{m}=14.0 \pm 0.4 \mathrm{mmol} / 1$, $n=1 \cdot 4 \pm 0 \cdot 1$ in control tissues, and Isc max $=74 \pm 1 \mu \mathrm{A} / \mathrm{cm}^{2}$, $K_{m}=11 \cdot 5 \pm 0 \cdot 2 \mathrm{mmol} / \mathrm{l}, n=2 \cdot 2 \pm 0 \cdot 1$ in dexamethasone treated tissues.

\section{Discussion}

As previously reported, ${ }^{1+1}$ the present study has shown that amiloride sensitive apical $\mathrm{Na}^{+}$channels are normally absent from rat distal colon, an epithelium in which $\mathrm{Na}^{+}$is absorbed predominantly by an electroneutral $\mathrm{Cl}^{-}$-dependent process. ${ }^{3}$ TEA sensitive apical $\mathrm{K}^{+}$channels are also virtually absent from rat distal colon, which is normally characterised in vitro by net $\mathrm{K}^{+}$absorption. ${ }^{15}$ As the electrochemical driving forces for $\mathrm{K}^{+}$across the apical and basolateral membranes are almost equal in control tissues, ${ }^{16}$ net $\mathrm{K}^{+}$absorption in vitro reflects the combined effects of (i) an apical $\mathrm{K}^{+}$absorptive process, which has the features of a $\mathrm{K}^{+}-\mathrm{H}^{+}$exchange, ${ }^{15}$ (ii) the absence of a significant apical $\mathrm{K}^{+}$conductance, which limits passive $\mathrm{K}^{+}$movement along its electrochemical gradient from cell to mucosal solution, ${ }^{16}$ and (iii) a relatively high basolateral membrane $\mathrm{K}^{+}$conductance, which favours passive $\mathrm{K}^{+}$movement from cell to serosal solution. ${ }^{16}$

Recent studies indicate that the effects of glucocorticoid hormones on colonic ion transport are time dependent: a single dose of dexamethasone $(600$ $\mu \mathrm{g} / 100 \mathrm{~g}$ body weight) stimulates $\mathrm{Na}^{+}$absorption and $\mathrm{K}^{+}$secretion, and increases pd in vivo after five hours, ${ }^{7}$ while $\mathrm{Na}^{+}-\mathrm{K}^{+}-\mathrm{ATPase}$ activity does not increase until a further seven to 19 hours have elapsed. ${ }^{71}$ We have shown that a single dose of dexamethasone produces changes at the apical membrane five hours later which have implications for the active (transcellular) movement of both $\mathrm{Na}^{+}$and $\mathrm{K}^{+}$. Dexamethasone induces amiloride sensitive $\mathrm{Na}^{+}$ channels which increase passive $\mathrm{Na}^{+}$movement into the cell down its electrochemical gradient, leading to an increase in electrogenic $\mathrm{Na}^{+}$absorption. The transepithelial responses to TEA (Table 3 ) and the positive correlation between the TEA sensitive and amiloride sensitive short circuit currents in the dexamethasone treated tissues (Fig. 1) indicate that the glucocorticoid also induces apical $\mathrm{K}^{+}$channels in parallel with the apical $\mathrm{Na}^{+}$channels. Although the effects of TEA on the apical membrane voltage and membrane resistance ratio were not determined in the present study, TEA has been shown to produce similar transepithelial changes, depolarise the apical membrane, and increase the membrane resistance ratio in distal colon from animals treated chronically with dexamethasone,${ }^{18}$ indicating that TEA does in fact inhibit a dexamethasone induced apical $\mathrm{K}^{+}$ conductance. The presence of apical $\mathrm{K}^{+}$channels in dexamethasone treated tissues alters the electrical driving force for $\mathrm{K}^{+}$across the apical membrane in such a way as to enhance $\mathrm{K}^{+}$movement from the cell (and ultimately from the serosal solution) to the mucosal solution.

The experiments in the nystatin treated tissues provided a means of expressing basolateral membrane $\mathrm{Na}^{+}-\mathrm{K}^{+}-$ATPase activity in terms of transport function-that is, a change in current generated by the $\mathrm{Na}^{+}-\mathrm{K}^{+}$pump in response to a change in intracellular $\mathrm{Na}^{+}$concentration, rather than the ability to release phosphate from ATP. As shown in Figure 2, Isc max $_{\text {max }}$ was similar in the control and dexamethasone treated tissues, indicating that dexamethasone had no effect on the $\mathrm{Na}^{+}$transport capacity of the basolateral membrane $\mathrm{Na}^{+}-\mathrm{K}^{+}$pump after five hours. This is in agreement with a previous study in which mucosal $\mathrm{Na}^{+}-\mathrm{K}^{+}$activity in rat distal colon was unchanged five hours after a similar single dose of dexamethasone. ${ }^{7}$ The other kinetic parameters derived from the data in Figure 2 show that the increase in electrogenic $\mathrm{Na}^{+}$transport seen in the dexamethasone treated tissues reflects a small but significant increase in the affinity of the $\mathrm{Na}^{+}-\mathrm{K}^{+}$ pump for $\mathrm{Na}^{+}$(as judged by the decrease in $\mathrm{K}_{\mathrm{m}}$ ), and a $57 \%$ increase in the number of $\mathrm{Na}^{+}$ions binding to each pump site. It should be noted that total $\mathrm{Na}^{+}-\mathrm{K}^{+}-$ATPase activity (and presumably $\mathrm{Isc}_{\text {max }}$ ) eventually increases $12-24$ hours after dexamethasone administration, ${ }^{717}$ but it is unclear whether this change is induced by a sustained increase in 
apical $\mathrm{Na}^{+}$entry, or whether it reflects a direct stimulatory effect of the glucocorticoid on maximal $\mathrm{Na}^{+}-\mathrm{K}^{+}-\mathrm{ATPase}$ activity in the basolateral membrane, as seen in the kidney. ${ }^{19} 20$

The time course of the transport effects of dexamethasone are consistent with the activation of corticosteroid receptors present in the colonic mucosa. ${ }^{21}$ Dexamethasone administered at high doses occupies mineralocorticoid as well as glucocorticoid receptors in the colonic cytosol. ${ }^{22}$ Recent studies, however, indicate that mineralocorticoids and glucocorticoids (including dexamethasone) induce changes in distal colonic $\mathrm{Na}^{+}$absorptive and $\mathrm{K}^{+}$secretory processes which are both qualitatively and quantitatively different, ${ }^{2.3}$ suggesting that they act through different types of corticosteroid receptor. The synthetic glucocorticoid RU 26988, which activates specific glucocorticoid receptors without binding to specific mineralocorticoid receptors, has also been shown to stimulate $\mathrm{Na}^{+}$absorption, $\mathrm{K}^{+}$secretion, and transmural pd in distal colon in adrenalectomised rats. ${ }^{23}$ The present study has shown that after activation of glucocorticoid receptors by dexamethasone, there is an early increase in the conductance of the apical membrane of the distal colon to $\mathrm{Na}^{+}$and $\mathrm{K}^{+}$ ions, and an increase in the 'efficiency' of the basolateral $\mathrm{Na}^{+}-\mathrm{K}^{+}$pump.

This study was supported in part by a grant from the North Western Regional Health Authority. Dr Sandle is a Medical Research Council Senior Fellow.

\section{References}

1 Bastl CP, Binder HJ, Hayslett JP. Role of glucocorticoids and aldosterone in maintenance of colonic cation transport. Am J Physiol 1980; 238: F181-F6.

2 Charney AN, Wallach J, Ceccarelli S, Donowitz M, Costenbader CL. Effects of spironolactone and amiloride on corticosteroid-induced changes in colonic function. Am J Physiol 1981; 241: G300-G5.

3 Foster ES, Zimmerman TW, Hayslett JP, Binder HJ. Corticosteroid alteration of active electrolyte transport in rat distal colon. Am J Physiol 1983; 245: G668-G75.

4 Jorkasky D, Cox M, Feldman GM. Differential effects of corticosteroids on $\mathrm{Na}^{+}$transport in rat distal colon in vitro. Am J Physiol 1985; 248: G424-G31.

5 Will PC, Cortright RN, DeLisle RC, Douglas JG, Hopfer U. Regulation of amiloride-sensitive electrogenic sodium transport in the rat colon by steroid hormones. Am J Physiol 1985; 248: G124-G32.

6 Clauss W, Durr J, Skadhauge E, Hornicke H. Effects of aldosterone and dexamethasone on apical membrane properties and Na-transport of rabbit distal colon in vitro. Pflugers Arch 1985; 403: 186-92.

7 Binder HJ. Effect of dexamethasone on electrolyte transport in the large intestinal of the rat. Gastroenterology 1978; 75: 212-7.

8 Sandle GI, Hayslett JP, Binder HJ. The effect of glucocorticoids on rectal transport in normal subjects and patients with ulcerative colitis. Gut 1986; 27: 309-16.

9 Sandle GI, Hayslett JP, Binder HJ. Effect of chronic hyperaldosteronism on the electrophysiology of rat distal colon. Pflugers Arch 1984; 401: 22-6.

10 Wills NK, Lewis SA, Eaton DC. Active and passive properties of rabbit descending colon. A microelectrode and nystatin study. J Membr Biol 1979; 45: 81-108.

11 Cass A, Finkelstein A, Krespi V. The ion permeability induced in thin lipid membranes by polyene antibiotics nystatin and amphotericin B. J Gen Physiol 1970; 50: 100-24.

12 Lewis SA, Wills NK. Interaction between apical and basolateral membranes during sodium transport across tight epithelia. In: Schultz SG, ed. Ion transport by epithelia, New York: Raven Press: 1981: 93-107.

13 Snedecor GW, Cochran WG. Statistical methods. Ames, Iowa: Iowa State University Press, 1967: 549.

14 Will PC, Lebowitz JL, Hopfer U. Induction of amiloride sensitive sodium transport in the rat colon by mineralocorticoids. Am J Physiol 1980; 238: F261-8.

15 Foster ES, Hayslett JP, Binder HJ. Mechanism of active potassium absorption and secretion in the rat colon. Am J Physiol 1984; 246: G611-G7.

16 Sandle GI, Foster ES, Lewis SA, Binder HJ, Hayslett JP. The electrical basis for enhanced potassium secretion in rat distal colon during dietary potassium loading. Pflugers Arch 1985; 403: 433-9.

17 Will PC, DeLisle RC, Cortright RN, Hopfer U. Induction of amiloride-sensitive sodium transport in the intestines by adrenal steroids. Ann NY Acad Sci 1981; 372: $64-78$.

18 Sandle GI. Glucocorticoid-induced Na and K channels in the apical membrane of rat distal colon. [Abstract]. Gut 1985; 26: A1146.

19 Finkelstein FO, Hayslett JP. Role of medullary Na-KATPase in renal potassium adaptation. Am J Physiol 1975; 229: 524-8.

20 Rodriquez HJ, Sihka SK, Starling J, Klahr S. Regulation of renal $\mathrm{Na}^{+}-\mathrm{K}^{+}-\mathrm{ATPase}$ in the rat byadrenal steroids. Am J Physiol 1981; 241: F186-F95.

21 Pressley L, Funder JW. Glucocorticoid and mineralocorticoid receptors in gut mucosa. Endocrinology 1975; 97: 588-96.

22 Marusic ET, Hayslett JP, Binder HJ. Corticosteroidbinding studies in cytosol of colonic mucosa of the rat. Am J Physiol 1981; 240: G417-G23.

23 Bastl CP, Barnett CA, Schmidt TJ, Litwack G. Glucocorticoid stimulation of sodium absorption in colon epithelia is mediated by corticosteroid IB receptor. J Biol Chem 1984; 259: 1186-95. 